Sains Malaysiana 50(11)(2021): 3373-3382

http://doi.org/10.17576/jsm-2021-5011-21

\title{
Preparation of Nano-Iron Loaded Cassava Fibre Composite Material for Hexavalent Chromium Removal
}

(Penyediaan Bahan Komposit Serabut Ubi Kayu Terisi Nanozarah Besi untuk Penyingkiran Kromium Heksavalen)

\author{
Haobin Shi, Wenbin Zhang, Feng Chen, Qingsheng Shi, Fei Chen, Li Fu* \& Shichao Zhao
}

\begin{abstract}
Waste cassava fiber and tea polyphenols were used as carrier materials and reducing agents, respectively, to prepare nano-iron loaded cassava fiber composite (CF-FeNPS). This work investigated the factors affecting the removal of $\mathrm{Cr}(V I)$ by CF-FeNPs under different environmental conditions and the removal mechanism. The SEM characterization results show that as the initial $\mathrm{Fe}^{2+}$ concentration increases, the amount of nano-iron on the surface of the composite material increases. The results show that the increases of the initial Fe ${ }^{2+}$ content and dosage of CF-FeNPss can enhance the removal rate. Meanwhile, the decrease of the initial concentration of Cr(VI) solution and $p H$ also beneficial for the removal performance. When $\mathrm{pH}=2.0$ and the initial concentration of $\mathrm{Cr}(\mathrm{VI})$ is $10 \mathrm{mg} / \mathrm{L}$, the removal rate of hexavalent chromium by CF-FeNPs can reach 81.4\% within $2 \mathrm{~h}$. The reaction conforms to the pseudo first-order kinetic model. The results of this study can provide technical reference for the remediation and treatment of Cr(VI)-containing wastewater.
\end{abstract}

Keywords: Nanocomposite; pollution control; removal mechanism; tea polyphenols; wastewater

ABSTRAK

Sisa serabut ubi kayu dan polifenol telah digunakan sebagai bahan pembawa dan agen penurun masing-masing untuk menghasilkan komposit serabut ubi kayu terisi nanozarah besi (CF-FeNPs). Penyelidikan ini mengkaji faktor yang mempengaruhi penyingkiran ion Cr(VI) oleh CF-FeNPs) pada keadaan persekitaran yang berbeza serta mekanisme penyingkiran. Pencirian menggunakan SEM menunjukkan bahawa peningkatan kepekatan Fe ${ }^{2+}$ telah meningkatkan kandungan nanozarah besi yang terbentuk pada permukaan komposit. Keputusan menunjukkan bahawa peningkatan kepekatan $\mathrm{Fe}^{2+}$ telah meningkatkan kadar penyingkiran Cr(VI). Pada pH=2.0 dan kepekatan awal Cr(VI) $10 \mathrm{mg} / \mathrm{L}$, penyingkiran Cr(VI) boleh mencapai setinggi 81.4\% dalam masa 2 jam. Tindak balas ini berpadanan dengan model kinetik tertib pertama pseudo. Keputusan kajian ini boleh menjadi rujukan teknikal bagi kajian rawatan air buangan yang mengandungi Cr(VI).

Kata kunci: Air buangan; kawalan pencemaran; komposit nano; mekanisme penyingkiran; polifenol teh

\section{INTRODUCTION}

$\mathrm{Cr}(\mathrm{VI})$ is a highly toxic heavy metal with high mobility and is difficult to be reduced by microorganisms. It is easy to accumulate in organisms through the food chain. Once it is discharged, it will bring lasting disasters to the environment (Dong et al. 2016). Therefore, $\mathrm{Cr}(\mathrm{VI})$ is considered to be one of the most harmful chemical substances to the human body, and is listed as one of the most toxic pollutants by the United States Environmental Protection Agency (USEPA) (Wang et al. 2017). Chromium mainly exists in the form of $\mathrm{Cr}(\mathrm{VI})$ and $\mathrm{Cr}$ (III) in nature
(Fu et al. 2013), among which Cr(VI) has strong mobility and is more toxic, which is 100 times that of $\mathrm{Cr}$ (III) (Zeng et al. 2019). Exposure to Cr(VI) is likely to cause carcinogenesis, teratogenesis and mutagenesis, and has serious damaging effects on people and the environment (Clementino et al. 2018). Therefore, removing Cr(VI) in polluted wastewater is the key to ensuring water quality and safety. $\mathrm{Cr}(\mathrm{VI})$ is a priority control pollutant among environmental metal pollutants (Fu et al. 2019; KarimiMaleh et al. 2021a, 2021b; Zhou et al. 2020). At present, the repair methods for $\mathrm{Cr}(\mathrm{VI})$ pollution in water bodies 
mainly include chemical methods (such as chemical reduction method (Dermentzis et al. 2012), electrolysis method (Qian et al. 2014), photocatalysis method (Sun et al. 2019)), physical methods (such as adsorption (Wei et al. 2013), ion exchange (Kalidhasan et al. 2013), membrane separation (Koushkbaghi et al. 2018)) and biological method (microbial remediation) (Batool et al. 2012), and plant adsorption (Banerjee et al. 2018). These methods have certain limitations, therefore, seek an environment friendly and quick response method is imperative.

Nano iron particles (FeNPs) have been widely used in the field of environmental remediation due to their unique physical and chemical properties, large specific surface area and high reactivity (Chen et al. 2017; Jing et al. 2016). Traditional nano-iron is usually prepared by high-energy ball milling (Wang et al. 2020), liquid-phase reduction (Bae et al. 2016) or pyrolysis of carbonyl iron (Kumar et al. 2018). However, the general physical methods have higher requirements for the equipment and the FeNPs morphology control ability is limited. They also include strong reducing agent (sodium borohydride or hydrazine hydrate) which is toxic and will cause environmental issues. In addition, the high surface energy of nanoparticles will cause oxidation and agglomeration, which reduces the reactivity.

The use of plant extracts as a reducing agent to synthesize iron nanoparticles as a green chemical technology with fast response, non-toxic, and environmentally friendly (Chavan et al. 2020). The use of plant extracts to synthesize nano iron can make full use of the active ingredients in natural plants to reduce the agglomeration problem of FeNPs due to its own magnetism with stable physical and chemical properties (Ebrahiminezhad et al. 2018). Machado et al. (2013) selected 26 plant leaf extracts to prepare FeNPs with a particle size of 10-20 nm. The results showed that the antioxidant properties of oak leaves, pomegranate leaves and green tea were relatively optimal. Wang et al. (2014) compared the FeNPs prepared from the eucalyptus leaf extract with the FeNPs synthesized by the traditional method. The degree of agglomeration of eucalyptus leafbased FeNPs is smaller and it is easier to store stably.

Tea leaf can be used for synthesizing by FeNPs due to its rich in antioxidants such as tea polyphenols, theaflavins, gallic acid, and flavonoids. These molecules can also effectively remove free radicals from the human body and inhibit the formation of active oxygen (Gautam et al. 2018). Huang et al. (2014) compared the performance of FeNPs prepared from green tea, oolong tea, and black tea. When green tea is used, the iron content is the highest, the size is the smallest, and the specific surface area is the largest. The degradation efficiency of malachite green can reach more than $80 \%$. The authors believe that this may be related to the higher content of polyphenols and caffeine in green tea. Ghanim et al. (2020) synthesized of FeNPs using black tea leaves extract as adsorbent for removing eriochrome blue-black B dye. It is reported that the toxicity of FeNPs obtained by reducing nitrate with tea polyphenols in tea extract is lower than that obtained when borohydride is used as a reducing agent (Plachtová et al. 2018).

The agglomeration of nanomaterials is an important issue for reducing performance. By introducing a substrate to support nanomaterials, the agglomeration of FeNPs can be reduced while maintaining the high reactivity. At the same time, this strategy can also enhance its stability and oxidation resistance, and improve the recovery rate. At the same time, the substrate also has a certain adsorption effect, which improves the ability of FeNPs to remove pollutants. According to reports, traditional substrate materials include: chitosan, silica, kaolin, zeolite, bentonite, clay, ion exchange resin and activated carbon (Mashayekhi et al. 2018). Considering the popularization and use of FeNPs in groundwater and soil environmental remediation, it is imperative to seek a substrate material with high economic and environmental benefits.

Cassava fiber is one of the main agricultural wastes obtained during the production of cassava starch. It has a large output with high processing cost. The large number of dumping will cause many environmental problems. In view of this, this article aims to make secondary comprehensive utilization of cassava fiber. In this study, FeNPs was loaded on low-cost cassava fiber to prepare FeNPs composite material for removing $\mathrm{Cr}(\mathrm{VI})$ in water. Tea polyphenols used as reducing agents can well prevent the agglomeration between FeNPs. This composite has a good catalytic degradation effect. This composite showed a good catalytic degradation effect. The optimum performance was studied by exploring the comparing of different factors such as FeNPs composites prepared by different initial $\mathrm{Fe}^{2+}$ concentrations, $\mathrm{pH}$, dosage and the initial $\mathrm{Cr}(\mathrm{VI})$ concentration. The morphology of the prepared FeNPs composite was characterized by SEM. The mechanism of composite for removing $\mathrm{Cr}(\mathrm{VI})$ from water was carried out as well. This work aims to provide a theoretical basis for the preparation of FeNPs composite and its application in environmental remediation. 


\section{MATERIALs AND METHODS}

The $\mathrm{Cr}(\mathrm{VI})$ solution used in the experiment is a national standard sample $(1000 \mu \mathrm{g} / \mathrm{L})$ (Zhang et al. 2017). Tea polyphenol (99\%), ferrous sulfate $\left(\mathrm{FeSO}_{4} \cdot 7 \mathrm{H}_{2} \mathrm{O}, \mathrm{AR}\right)$ and diphenyl semicarbazide $\left(\mathrm{C}_{13} \mathrm{H}_{14} \mathrm{~N}_{4} \mathrm{O}, \mathrm{AR}\right)$ were purchased from Macleans Reagent Co., Ltd. Acetone $\left(\mathrm{C}_{3} \mathrm{H}_{6} \mathrm{O}, \mathrm{AR}\right)$, sulfuric acid $\left(\mathrm{H}_{2} \mathrm{SO}_{4}, \mathrm{GR}\right)$ and phosphoric acid $\left(\mathrm{H}_{3} \mathrm{PO}_{4}\right.$, AR) were purchased from Sinopharm Chemical Reagent Co., Ltd. Anhydrous ethanol $\left(\mathrm{CH}_{3} \mathrm{CH}_{2} \mathrm{OH}, \mathrm{AR}\right)$ was purchased from Hangzhou Gaojing Fine Chemical Co., Ltd. The experiment uses deionized water. Cassava Fiber (CF) was taken from Zhejiang Huaxin Agricultural Biotechnology Co., Ltd. The cassava fiber was dried in a blast drying box at $60{ }^{\circ} \mathrm{C}$ for $12 \mathrm{~h}$ and then cooled. The fiber then ground to obtain cassava fiber powder. The $\mathrm{CF}$ powder was placed in a drying container for use.

$10 \mathrm{~g} / \mathrm{L}$ tea polyphenols (TP) solution was slowly added dropwise to $0.4 \mathrm{M} \mathrm{FeSO}_{4}$ solution, under the condition of magnetic stirring at room temperature. After the reaction for $2 \mathrm{~h}$, the black solid (FeNPs) was obtained by centrifugation, which was washed twice with deionized water and ethanol solution. When the tea polyphenol solution was added to the ferrous sulfate solution, the solution gradually changed from light bluegreen to indigo blue and then to black, indicating the formation of FeNPs suspension, as shown in Figure 1.

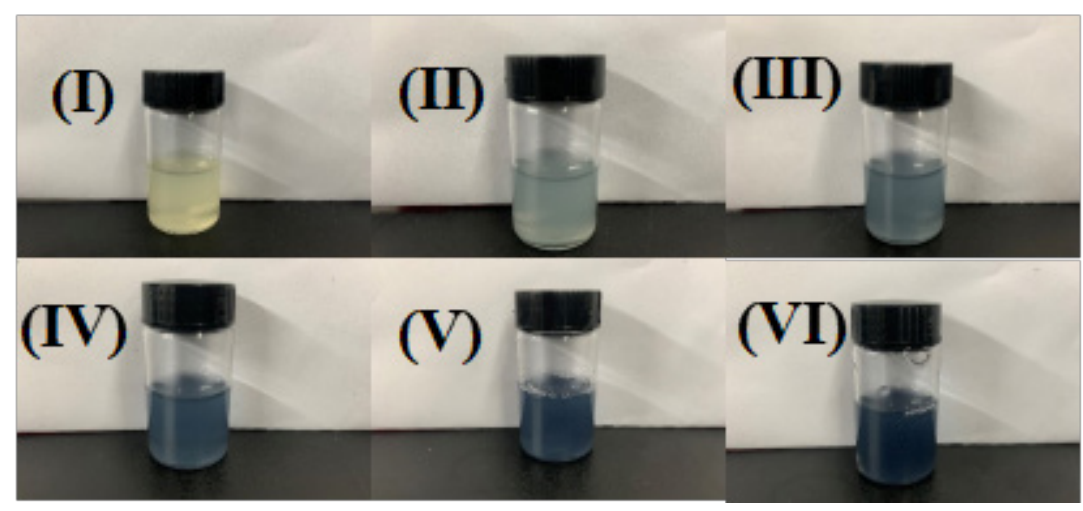

FIGURE 1. The process of ferrous sulfate solution when slowly add tea polyphenols solution (I) - (VI)

Fifty $\mathrm{mg}$ of cassava fiber powder was added into $\mathrm{FeSO}_{4}$ solution of the same concentration and magnetically stir at room temperature for $8 \mathrm{~h}$. Then, 10 $\mathrm{g} / \mathrm{L}$ tea polyphenol solution was added dropwise, react under magnetic stirring for $2 \mathrm{~h}$ and centrifuge to obtain black solid powder (CF-FeNPs), and washed twice with deionized water and ethanol solution. After drying these two materials in an oven, the sample was collected at room temperature after grinding for later use.

A batch experiment was used to determine the efficiency of CF, FeNPs, and CF-FeNPs in removing $\mathrm{Cr}(\mathrm{VI})$ in aqueous solution. CF, FeNPs, and CF-FeNPs were added into a $40 \mathrm{~mL}$ sample bottle. Then, $10 \mathrm{mg} / \mathrm{L}$ $(20 \mathrm{~mL})$ of $\mathrm{Cr}(\mathrm{VI})$ solution was added under stirring at a constant speed ( $250 \mathrm{r} / \mathrm{min})$ and a constant temperature (25 $\left.{ }^{\circ} \mathrm{C}\right) .0 .1 \mathrm{M} \mathrm{H} 2 \mathrm{SO} 4$ has been used to adjusts the $\mathrm{pH}$ of the solution. Sample has been taken at regular intervals and immediately filtered using a $0.22 \mu \mathrm{m}$ membrane filter, and then measured the residual chromium in the solution. All experiments were performed in duplicate, and the results were averaged.

An ultraviolet-visible spectrophotometer (759UV1600, Shanghai, China) was used to determine the concentration of $\mathrm{Cr}(\mathrm{VI})$ at $540 \mathrm{~nm}$ using the diphenyl semicarbazide method (Janghel et al. 2007). The morphology of different materials was characterized by SEM.

The Cr(VI) removal efficiency of CF-FeNPs composite material is expressed by the following equation:

$$
R(\%)=\frac{\left(C_{0}-C_{e}\right)}{C_{0}} \times 100 \%
$$

where $\mathrm{C}_{0}$ and $\mathrm{C}_{\mathrm{e}}$ are the initial and equilibrium liquid phase concentrations of $\mathrm{Cr}(\mathrm{VI})$, respectively.

Kinetic analysis of reaction between composite materials and $\mathrm{Cr}(\mathrm{VI})$ is a complex reaction that occurs on the surface of the material. The pseudo-first-order 
kinetic equation simplifies the Langmuir-Hinshelwood first reaction kinetic model. The equation is as follows:

$$
\ln \left(\frac{\mathrm{C}_{\mathrm{t}}}{\mathrm{C}_{0}}\right)=-\mathrm{k}_{\mathrm{obs}} \mathrm{t}
$$

where $\ln \left(\mathrm{C}_{\mathrm{t}} / \mathrm{C}_{0}\right)$ has a linear relationship with $\mathrm{t} ; \mathrm{k}_{\mathrm{obs}}$ is the apparent rate constant; $\mathrm{C}_{\mathrm{t}}$ is the concentration at time $\mathrm{t}$; and $\mathrm{C}_{0}$ is the initial concentration.

\section{RESULTS AND DISCUSSION}

Figure 2 shows the morphology of CF, FeNPs, and CF-FeNPs. Figure 2(a) shows the $\mathrm{CF}$ with a rough morphology. Figure 2(b) shows the FeNPs prepared using tea polyphenols as a reducing agent. FeNPs are mainly spherical with spherical nodules. The particle size is between $80-150 \mathrm{~nm}$. The FeNPs are constructed by a polyphenol polymer network. Figure 2(c)-2(f) are CF-FeNPs composites prepared under different concentrations of ferrous sulfate $(0.1 \mathrm{M}-0.4 \mathrm{M})$. With the increase of precursor concentration, the number of attached nanoparticles can be obviously observed in CFFeNPs composites. The loaded FeNPs mainly exist in the form of spheres compounded into popcorn shape. The originally rough surface of CF becomes smooth as well. Since the polyphenol-iron polymerization network produced during the reaction covers the surface of $\mathrm{CF}$, the number of agglomerations is greatly reduced compared to pure FeNPs. Compared with previous reports, the FeNPs loaded on the CF showed a much uniform size (Mehrotra et al. 2017; Yin et al. 2021).

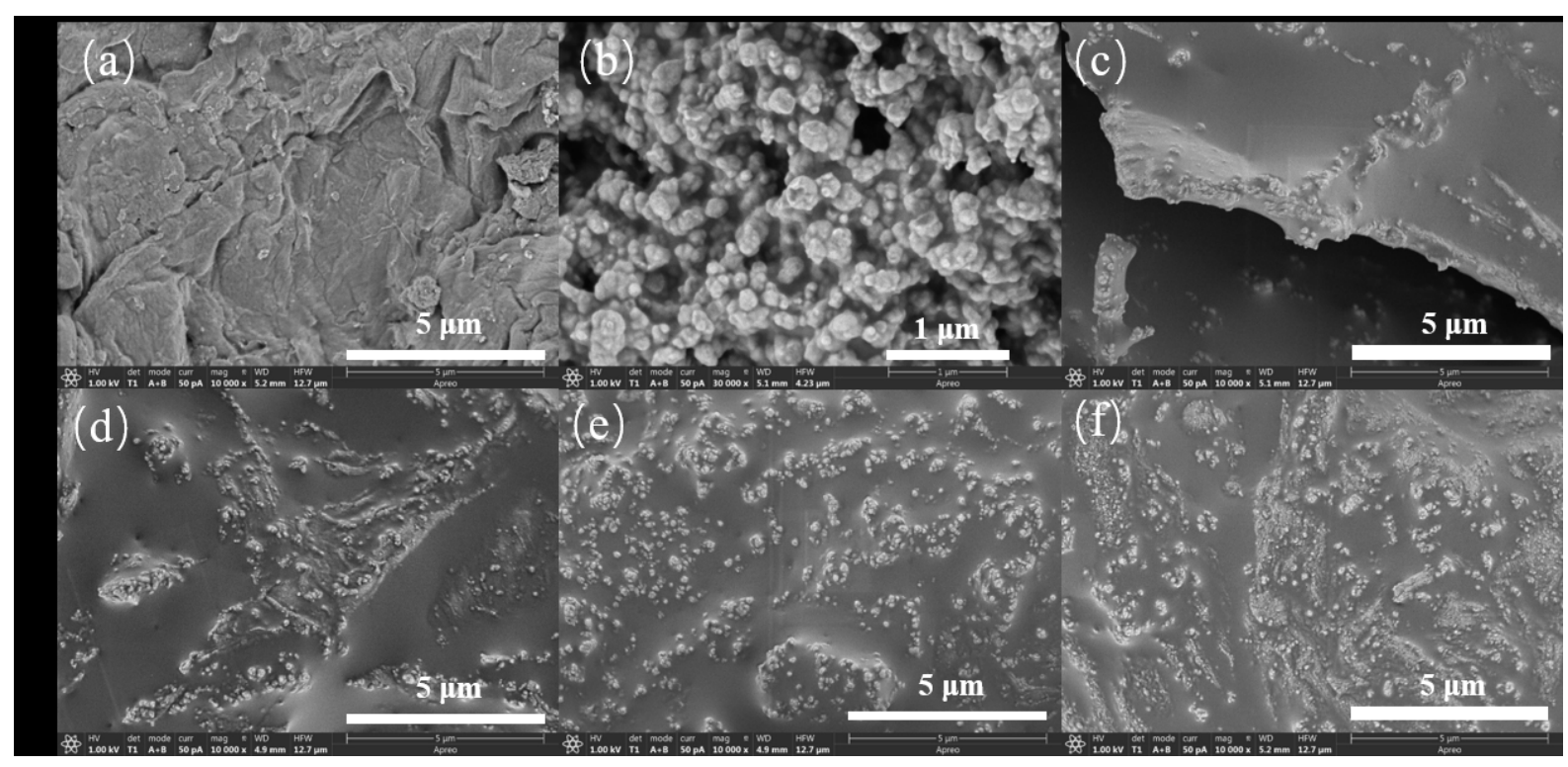

FIGURE 2. SEM images of (a) cassava fiber; (b) synthetic FeNPs; and (c) (f)

CF-FeNPs synthesized under different concentrations of precursor $(0.1 \mathrm{M}-0.4 \mathrm{M})$

First, we studied the adsorption effect of different materials on hexavalent chromium. Figure 3 shows the removal efficiency of $\mathrm{CF}$, FeNPs, and CF-FeNPs for $\mathrm{Cr}(\mathrm{VI})$ in aqueous solution. The removal efficiency of $\mathrm{CF}$ can only reach about $9 \%$ after $2 \mathrm{~h}$. As a kind of plant fiber, $\mathrm{CF}$ can adsorb $\mathrm{Cr}(\mathrm{VI})$ on the fiber surface through physical adsorption. By using pure synthetic FeNPs, the removal efficiency is slowly increased from $24.7 \%$ in 15 min to $62.3 \%$ in $4 \mathrm{~h}$. FeNPs have a reducing effect on metal ions and surface adsorption and complexation. The slow increase in removal efficiency may be due to the aggregation of FeNPs. When CF is used as the supporting substrate to load FeNPs, the removal rate is increased to $67.3 \%$ in $2 \mathrm{~h}$ and $81.4 \%$ in $4 \mathrm{~h}$, which is much higher than the removal efficiency of ordinary cassava fiber and synthetic FeNPs.

Due to the improvement of the $\mathrm{Cr}(\mathrm{VI})$ removal efficiency of CF-FeNPs composite materials, we further studied the effect of CF-FeNPs prepared with different concentrations of precursor on the removal of $\mathrm{Cr}(\mathrm{VI})$. The 
results are shown in Figure 4(a), the removal efficiency of CF-FeNPs for Cr(VI) only reached $42.4 \%$ and $54.3 \%$ in $4 \mathrm{~h}$, using $0.1 \mathrm{M}$ and $0.2 \mathrm{M}$ precursor, respectively. This is a significant improvement in the removal efficiency of $\mathrm{CF}$, but it is $20 \%$ and $8 \%$ less than pure FeNPs. This indicates that when the $\mathrm{Fe}^{2+}$ concentration increases, the removal efficiency of $\mathrm{Cr}(\mathrm{VI})$ will also increase due to the increase in the number of FeNPs loaded on the surface of the prepared composite material. When the concentration of ferrous sulfate gradually increased to $0.3 \mathrm{M}$, the removal efficiency of $\mathrm{Cr}(\mathrm{VI})$ reached $66.4 \%$ within $4 \mathrm{~h}$, which was comparable to the removal efficiency of bare FeNPs. As the concentration further increased to $0.4 \mathrm{M}-0.5 \mathrm{M}$, the removal efficiency of CF-FeNPs for $\mathrm{Cr}(\mathrm{VI})$ reached $81.4 \%$ and $80.9 \%$ within $4 \mathrm{~h}$, respectively. In summary, we chose $0.4 \mathrm{M}$ for the preparation of CF-FeNPs.

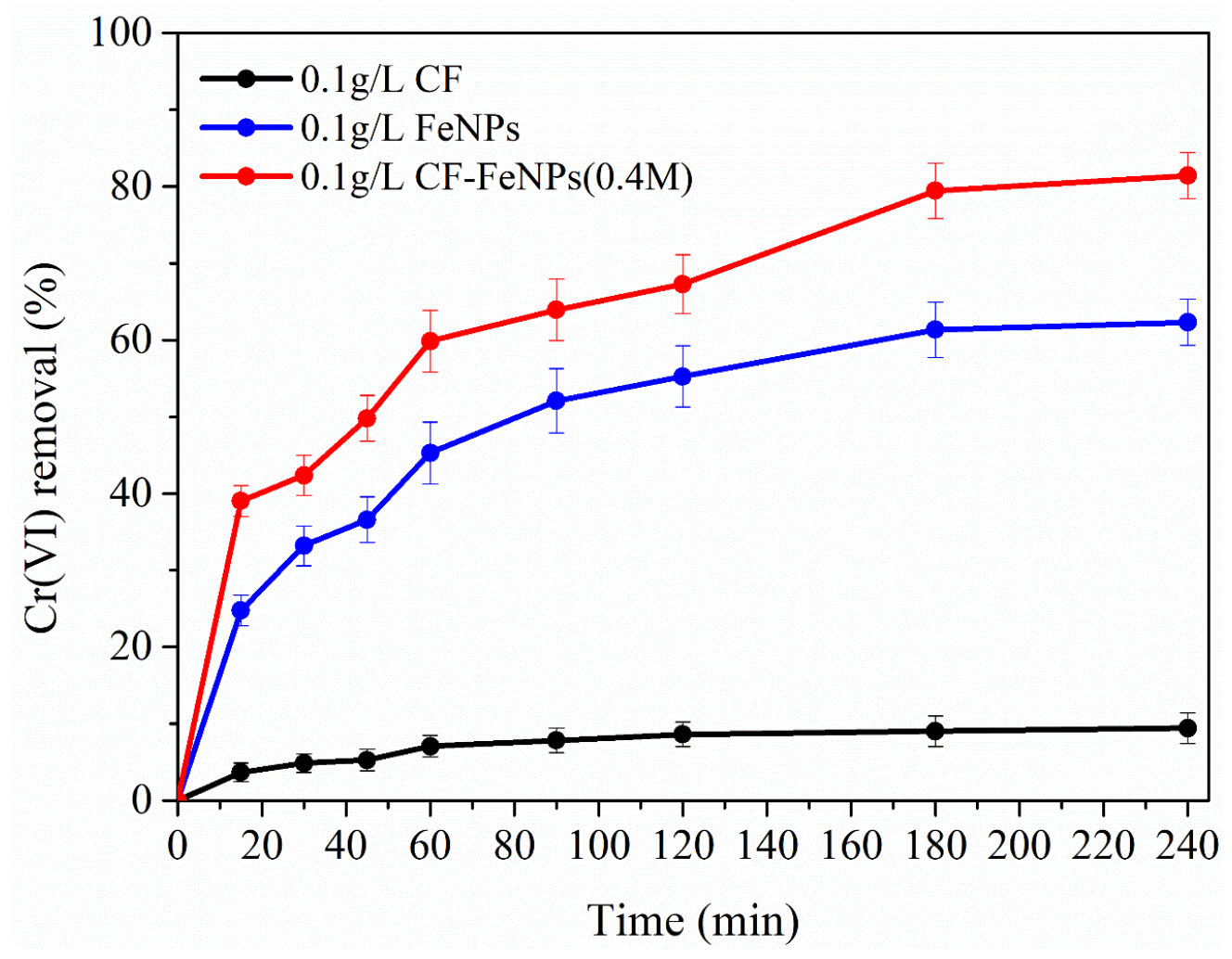

FIGURE 3. The effect of different materials on the removal of $\mathrm{Cr}$ (VI) (initial $\mathrm{Cr}(\mathrm{VI})$ concentration is $10 \mathrm{mg} / \mathrm{L}, \mathrm{Fe}^{2+}$ concentration is $0.4 \mathrm{M}, \mathrm{CF}-\mathrm{FeNPs}$ dosage is $0.1 \mathrm{~g} / \mathrm{L}, \mathrm{pH}=2.0, \mathrm{n}=3$ )

As an important environmental factor, $\mathrm{pH}$ has a great influence on the adsorption reaction and the reduction of zerovalent iron (Patel et al. 2020). The lower the $\mathrm{pH}$, the more conducive to the dissolution of iron, and more $\mathrm{Fe}^{2+}$ is generated, which helps the pollutants react on the surface of FeNPs. In addition, under weakly acidic conditions, the surface of FeNPs is more likely to be positively charged. Electrostatic attraction makes it easier for the negatively charged anions $\mathrm{CrO}_{4}{ }^{2-}$ $\mathrm{CrO}_{7}^{2-}$ have contact reactions on the surface, thereby promoting the reduction of $\mathrm{Cr}(\mathrm{VI})$. When $\mathrm{pH}<6.5, \mathrm{Cr}(\mathrm{VI})$ mainly exists in the form of $\mathrm{HCrO}_{4}^{-}$(Mohan \& Pittman
Jr. 2006), and iron mainly exists in the form of $\mathrm{Fe}^{2+}$ and $\mathrm{Fe}^{3+}$. Figure 4(b) shows the removal effect of CF-FeNPs on $\mathrm{Cr}(\mathrm{VI})$ at $\mathrm{pH}=2,3,4,5,6$. With the decrease of $\mathrm{pH}$, the removal efficiency of $\mathrm{Cr}(\mathrm{VI})$ by CF-FeNPs increased significantly. When $\mathrm{pH}=2$, the removal rate after $4 \mathrm{~h}$ can reach $81.4 \%$, while when $\mathrm{pH}=6$, the removal rate after 4 $\mathrm{h}$ is only $30.2 \%$. The reaction equation of nano-iron and $\mathrm{Cr}(\mathrm{VI})$ is as follows:

$$
\begin{aligned}
& 2 \mathrm{HCrO}_{4}^{-}+3 \mathrm{Fe}^{0}+14 \mathrm{H}^{+} \rightarrow 2 \mathrm{Cr}^{3+}+3 \mathrm{Fe}^{2+}+8 \mathrm{H}_{2} \mathrm{O} \\
& \mathrm{HCrO}_{4}^{-}+3 \mathrm{Fe}^{2+}+7 \mathrm{H}+\rightarrow \mathrm{Cr}^{3+}+3 \mathrm{Fe}^{3+}+4 \mathrm{H}_{2} \mathrm{O}
\end{aligned}
$$


Converted into units, when $\mathrm{pH}=2$ and the initial concentration of $\mathrm{Cr}(\mathrm{VI})$ is $10 \mathrm{mg} / \mathrm{L}$, the removal of $\mathrm{Cr}(\mathrm{VI})$ by the composite material with the dosage of $0.1 \mathrm{~g} / \mathrm{L}$ is $81.4 \mathrm{mg} / \mathrm{g}$.

Figure 4(c) shows the removal efficiency of CFFeNPs composite material on $\mathrm{Cr}(\mathrm{VI})$. It can be seen from the figure that as the dosage of CF-FeNPs composite material increases, more reactive sites are correspondingly increased, and the removal efficiency of $\mathrm{Cr}(\mathrm{VI})$ shows an increasing trend (Karimi-Maleh et al. 2020; Wei et al. 2017). In the early stage of the reaction, high material reactivity has more active sites to participate in the reaction. In the late stage of the reaction, the composite material is passivated and adsorbed on the surface of the material, thereby reducing the active sites of the reaction. The pollutant loses the opportunity to contact the material, and the transfer of electrons is therefore hindered, causing the removal rate to not be continuously and effectively improved. When the dosage reaches $0.2 \mathrm{~g} / \mathrm{L}$, $\mathrm{Cr}(\mathrm{VI})$ in the solution can be basically removed after $2 \mathrm{~h}$. In the follow-up experiment, based on the consideration of economic cost, we used CF-FeNPs composite material with a dosage of $0.2 \mathrm{~g} / \mathrm{L}$ for investigation.

The effect of different initial $\mathrm{Cr}(\mathrm{VI})$ concentrations $(10-30 \mathrm{mg} / \mathrm{L})$ on the removal efficiency is shown in Figure $4(d)$. With the increase of the initial $\mathrm{Cr}(\mathrm{VI})$ solution concentration, the removal rate of CF-FeNPs composites also decreased. When the concentration of $\mathrm{Cr}(\mathrm{VI})$ solution is $10 \mathrm{mg} / \mathrm{L}$, the removal rate within $4 \mathrm{~h}$ is $99.4 \%$. When the concentration of $\mathrm{Cr}(\mathrm{VI})$ solution is $20 \mathrm{mg} / \mathrm{L}$, the removal rate is $72.4 \%$. When the concentration of $\mathrm{Cr}(\mathrm{VI})$ solution is $30 \mathrm{mg} / \mathrm{L}$, the removal rate is $53.7 \%$. A certain amount of CF-FeNPs means that the effective surface of the material is certain, that is, the surface active sites are limited (Xu et al. 2020; Ying et al. 2020; Zhang et al. 2020a, 2020b). Since the $\mathrm{Cr}(\mathrm{VI})$ is transferred to the surface of nanoparticles through competitive adsorption, the increasing concentration of $\mathrm{Cr}(\mathrm{VI})$ in the solution reduces the contact probability between the $\mathrm{Cr}(\mathrm{VI})$ ions and nanoparticles. This results in a part of $\mathrm{Cr}(\mathrm{VI})$ unable to contact the surface active sites of the CF-FeNPs composite material, thereby reducing the removal rate.
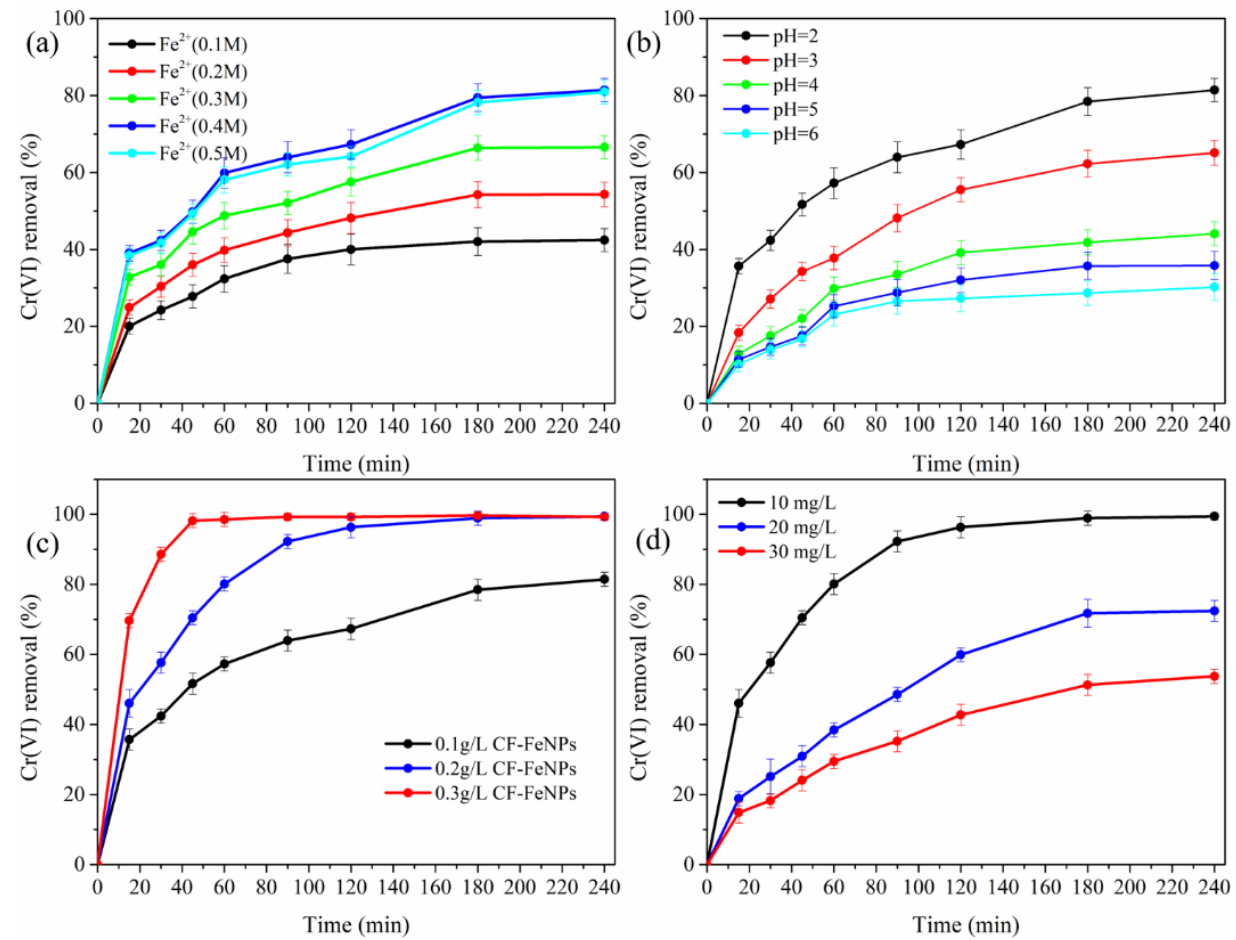

FIGURE 4. (a) The effect of different $\mathrm{Fe}^{2+}$ concentrations on the removal of $\mathrm{Cr}(\mathrm{VI})$ (the initial $\mathrm{Cr}(\mathrm{VI})$ concentration is $10 \mathrm{mg} / \mathrm{L}$, dosage of CF-FeNPs is $0.1 \mathrm{~g} / \mathrm{L}$, solution $\mathrm{pH}=2.0$ ); (b) The effect of different $\mathrm{pHs}$ on the remove $\mathrm{Cr}(\mathrm{VI})$ (initial $\mathrm{Cr}(\mathrm{VI})$ concentration is $10 \mathrm{mg} / \mathrm{L}, \mathrm{Fe}^{2+}$ concentration is $0.4 \mathrm{M}$, CFFeNPs dosage is $0.1 \mathrm{~g} / \mathrm{L}$ ); (c) The influence of different dosages on the removal of $\mathrm{Cr}(\mathrm{VI})$ (the initial concentration of $\mathrm{Cr}(\mathrm{VI})$ is $10 \mathrm{mg} / \mathrm{L}$, the concentration of $\mathrm{Fe}^{2+}$ is $0.4 \mathrm{M}$, solution $\mathrm{pH}=2.0$ ); (d) The effect of different initial concentrations on the removal of $\mathrm{Cr}(\mathrm{VI})\left(\mathrm{Fe}^{2+}\right.$ concentration is $0.4 \mathrm{M}$, the dosage of CF-FeNPs is $0.2 \mathrm{~g} / \mathrm{L}$, solution $\mathrm{pH}=2.0, \mathrm{n}=3$ ) 
The effect of the stability of CF-FeNPs composite material on the $\mathrm{Cr}(\mathrm{VI})$ removal efficiency is shown in Figure 5. Within half a month, with the increase of the
CF-FeNPs composite material's parking time, the removal efficiency of $\mathrm{Cr}(\mathrm{VI})$ is slowly decreasing, and the material removal efficiency is reduced by $9 \%$.

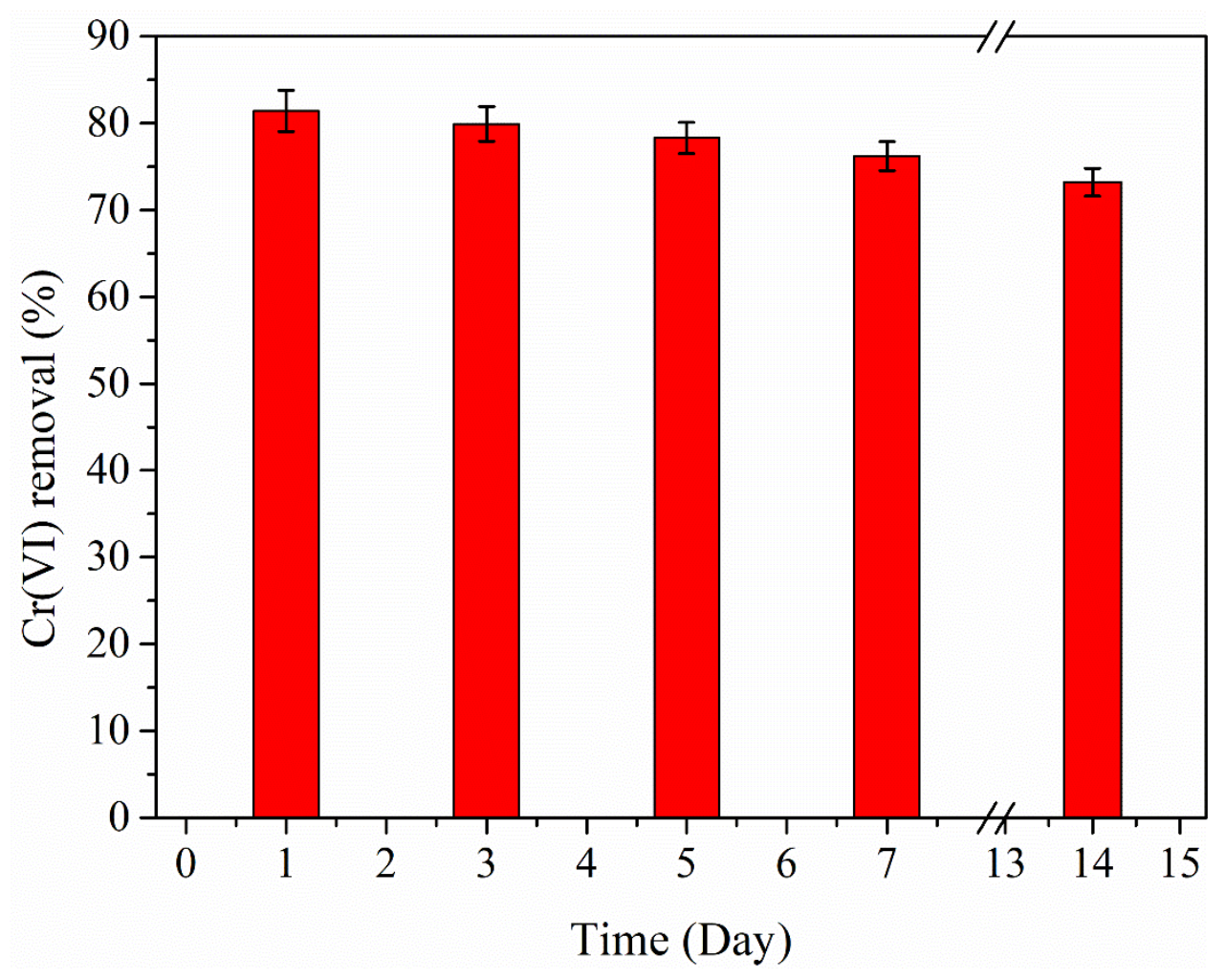

FIGURE 5. Influence of stability performance (initial $\mathrm{Cr}(\mathrm{VI})$ concentration is $10 \mathrm{mg} / \mathrm{L}$, amount of CF-FeNPs is $0.1 \mathrm{~g} / \mathrm{L}$, solution $\mathrm{pH}=2.0, \mathrm{n}=3$ )

The pseudo-first-order kinetic model is used to describe the kinetic characteristics of the removal of $\mathrm{Cr}(\mathrm{VI})$ from water by the CF-FeNPs composite material under the experimental design more accurately. This shows that chemical adsorption is the rate-limiting step in this reaction, and adsorption is a mass transfer process. The chemical reaction in this process is also controlled by other mechanisms, such as internal and external particle diffusion, complexes, and ion exchange (Paunovic et al. 2020; Shalaby \& Mohamed 2020).

The fitting results of the pseudo first-order kinetics are shown in Figure 6. The calculations in this figure correspond to Figure 4. As shown in Figure 6(a), as the initial concentration of $\mathrm{Fe}^{2+}$ increases, the corresponding reaction rate increases from $0.0028 \mathrm{~min}^{-1}\left(0.1 \mathrm{M} \mathrm{Fe}^{2+}\right)$ to
$0.00658 \mathrm{~min}^{-1}\left(0.1 \mathrm{M} \mathrm{Fe}^{4+}\right)$. Figure 6(b) shows the effect of solution $\mathrm{pH}$. When the $\mathrm{pH}$ is 2 and the dosage is 0.1 $\mathrm{g} / \mathrm{L}$, the largest rate constant and the highest removal rate are $0.00658 \mathrm{~min}^{-1}$ and $81.4 \%$, respectively. However, when the $\mathrm{pH}$ rises to 6 , the rate constant $\mathrm{k}_{\text {obs }}$ decreases to $0.0239 \mathrm{~min}^{-1}$. Figure 6(c) shows the effect of dosage. The reaction rate constant shows a trend that increases with the increase of dosage. When the dosage is $0.3 \mathrm{~g} / \mathrm{L}$, it corresponds to $0.0471 \mathrm{~min}^{-1}$. The results of the kinetic fitting corresponding to the concentration changes are shown in Figure 6(d), and the corresponding reaction rate constants are $0.0182,0.00669$, and $0.00365 \mathrm{~min}^{-1}$. Through kinetic analysis, the prepared CF-FeNPs composite material has a good removal efficiency for a lower concentration of $\mathrm{Cr}(\mathrm{VI})$ solution under acidic conditions. 

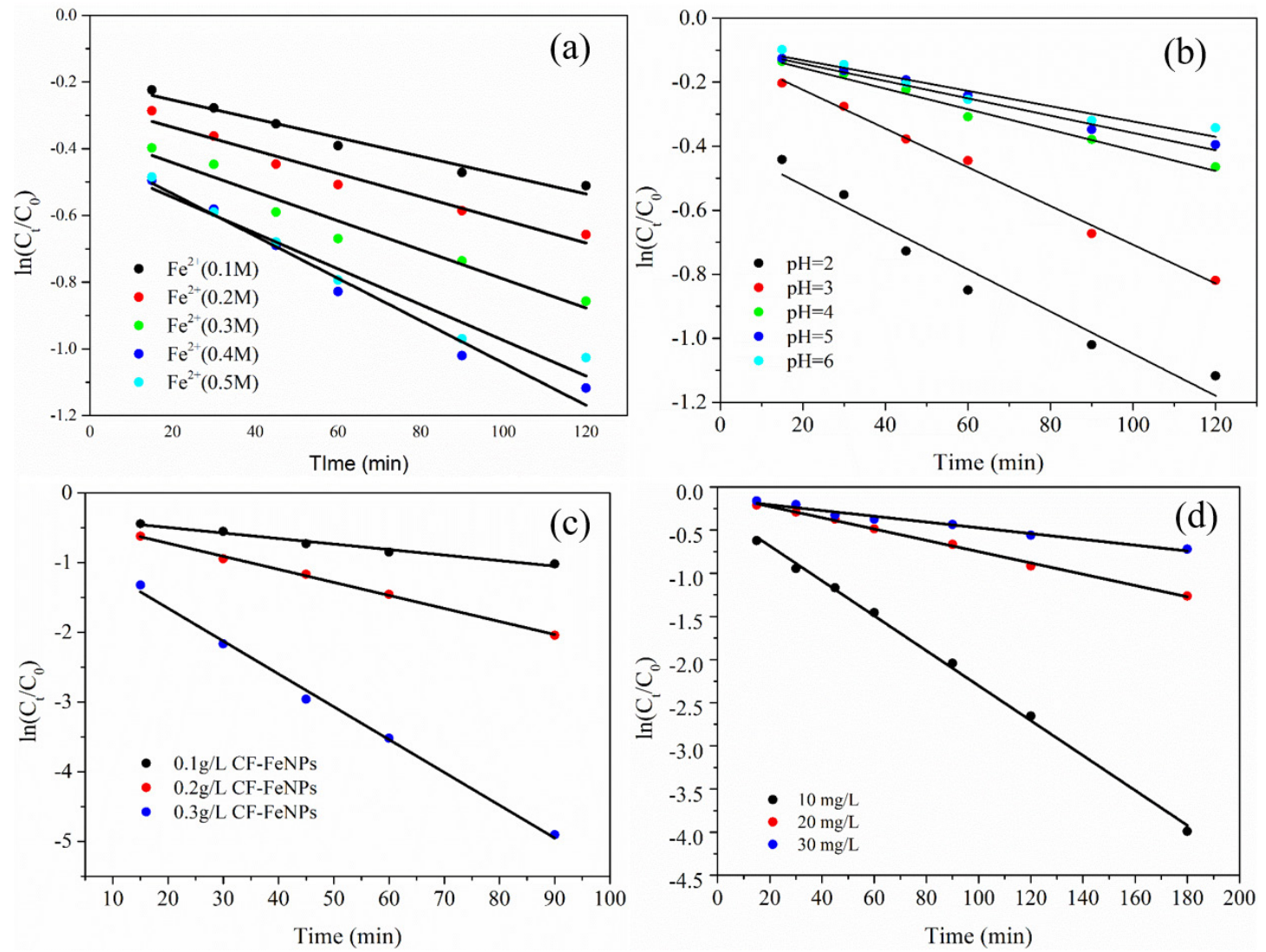

FIGURE 6. Pseudo first-order kinetic fitting results of different (a) $\mathrm{Fe}^{2+}$ concentration; (b) initial $\mathrm{pH}$ of solution; (c) dosage; and (d) $\mathrm{Cr}(\mathrm{VI})$ initial concentration

\section{CONCLUSION}

Under the experimental conditions of this study, increasing the $\mathrm{Fe}^{2+}$ concentration and the dosage of composite materials, while keeping the low initial concentration and $\mathrm{pH}$ value, is beneficial to the removal of $\mathrm{Cr}(\mathrm{VI})$ by CF-FeNPs composite. The removal rate of $\mathrm{Cr}(\mathrm{VI})$ by the CF-FeNPs composite can reaches $81.4 \%$ when the $\mathrm{pH}$ and initial concentration of $\mathrm{Cr}(\mathrm{VI})$ were 2 and $10 \mathrm{mg} / \mathrm{L}$ within $2 \mathrm{~h}$, respectively. Under the optimal reaction conditions, the mechanism of removing $\mathrm{Cr}(\mathrm{VI})$ using CF-FeNPs composite can be summarized as a complex and coexisting reduction-coupled adsorption co-precipitation process. The FeNPs loaded on CF can be recommended for wastewater treatment.

\section{ACKNOWLEDGEMENTS}

This work was funded by The National Key Research and Development Program of China (2017YFD0202100).

\section{REFERENCES}

Bae, S., Gim, S., Kim, H. \& Khalil, H. 2016. Effect of NaBH4 on properties of nanoscale zero-valent iron and its catalytic activity for reduction of p-nitrophenol. Applied Catalysis B: Environmental 182: 541-549.

Banerjee, M., Basu, R.K. \& Das, S.K. 2018. Cr (VI) adsorption by a green adsorbent walnut shell: Adsorption studies, regeneration studies, scale-up design and economic feasibility. Process Safety and Environmental Protection 116: 693-702.

Batool, R., Kim, Y. \& Shahida Hasnain. 2012. Hexavalent chromium reduction by bacteria from tannery effluent. $J$. Microbiol. Biotechnol. 22(4): 547-554.

Chavan, R.R., Bhinge, S.D., Bhutkar, M.A., Randive, D.S., Wadkar, G.H., Todkar, S.S. \& Urade, M.N. 2020. Characterization, antioxidant, antimicrobial and cytotoxic activities of green synthesized silver and iron nanoparticles using alcoholic Blumea eriantha DC plant extract. Materials Today Communications 24: 101320. 
Chen, A., Shang, C., Shao, J., Zhang, J. \& Huang, H. 2017. The application of iron-based technologies in uranium remediation: A review. Science of The Total Environment 575: 1291-1306.

Clementino, M., Shi, X. \& Zhang, Z. 2018. Oxidative stress and metabolic reprogramming in $\mathrm{Cr}(\mathrm{VI})$ carcinogenesis. Current Opinion in Toxicology 8: 20-27.

Dermentzis, K., Valsamidou, E. \& Marmanis, D. 2012. Simultaneous removal of acidity and lead from acid lead battery wastewater by aluminum and iron electrocoagulation. Journal of Engineering Science \& Technology Review 5(2): 1-5.

Dong, H., Zeng, Y., Zeng, G., Huang, D., Liang, J., Zhao, F., He, Q., Xie, Y. \& Wu, Y. 2016. EDDS-assisted reduction of Cr (VI) by nanoscale zero-valent iron. Separation and Purification Technology 165: 86-91.

Ebrahiminezhad, A., Zare-Hoseinabadi, A., Sarmah, A.K., Taghizadeh, S., Ghasemi, Y. \& Berenjian, A. 2018. Plantmediated synthesis and applications of iron nanoparticles. Molecular Biotechnology 60(2): 154-168.

Fu, F., Ma, J., Xie, L., Tang, B., Han, W. \& Lin, S. 2013. Chromium removal using resin supported nanoscale zerovalent iron. Journal of Environmental Management 128: 822-827.

Fu, L., Xie, K., Wang, A., Lyu, F., Ge, J., Zhang, L., Zhang, H., Su, W., Hou, Y.L., Zhou, C., Wang, C. \& Ruan, S. 2019. High selective detection of mercury (II) ions by thioether side groups on metal-organic frameworks. Analytica Chimica Acta 1081: 51-58. https://doi.org/10.1016/j. aca.2019.06.055.

Gautam, A., Rawat, S., Verma, L., Singh, J., Sikarwar, S., Yadav, B.C. \& Kalamdhad, A.S. 2018. Green synthesis of iron nanoparticle from extract of waste tea: An application for phenol red removal from aqueous solution. Environmental Nanotechnology, Monitoring \& Management 10: 377-387.

Ghanim, D., Al-Kindi, G.Y. \& Hassan, A.K. 2020. Green synthesis of iron nanoparticles using black tea leaves extract as adsorbent for removing eriochrome blue-black B dye. Engineering and Technology Journal 38(10A): 15581569.

Huang, L., Weng, X., Chen, Z., Megharaj, M. \& Naidu, R. 2014. Green synthesis of iron nanoparticles by various tea extracts: Comparative study of the reactivity. Spectrochimica Acta Part A: Molecular and Biomolecular Spectroscopy 130: 295-301.

Janghel, E.K., Rai, M.K., Gupta, V.K. \& Rai, J.K. 2007. Trace spectrophotometric determination of dichlorvos using diphenyl semicarbazide (DPC) in environmental and agricultural samples. Journal of the Chinese Chemical Society 54(2): 345-350.

Jing, C., Li, Y.L. \& Landsberger, S. 2016. Review of soluble uranium removal by nanoscale zero valent iron. Journal of Environmental Radioactivity 164: 65-72.
Kalidhasan, S., Krishna Kumar, A.S., Rajesh, V. \& Rajesh, N. 2013. Enhanced adsorption of hexavalent chromium arising out of an admirable interaction between a synthetic polymer and an ionic liquid. Chemical Engineering Journal 222: 454-463.

Karimi-Maleh, H., Alizadeh, M., Orooji, Y., Karimi, F., Baghayeri, M., Rouhi, J., Tajik, S., Beitollahi, H., Agarwal, S., Gupta, V.K., Rajendran, S., Rostamnia, S., Fu, L., Saberi-Movahed, F. \& Malekmohammadi, S. 2021 a. Guanine-based DNA biosensor amplified with Pt/ SWCNTs nanocomposite as analytical tool for nanomolar determination of daunorubicin as an anticancer drug: A docking/experimental investigation. Industrial \& Engineering Chemistry Research 60(2): 816-823. https://doi. org/10.1021/acs.iecr.0c04698.

Karimi-Maleh, H., Ayati, A., Davoodi, R., Tanhaei, B., Karimi, F., Malekmohammadi, S., Orooji, Y., Fu, L. \& Sillanpää, M. 2021b. Recent advances in using of chitosan-based adsorbents for removal of pharmaceutical contaminants: A review. Journal of Cleaner Production 291: 125880. https:// doi.org/10.1016/j.jclepro.2021.125880.

Karimi-Maleh, H., Orooji, Y., Ayati, A., Qanbari, S., Tanhaei, B., Karimi, F., Alizadeh, M., Rouhi, J., Fu, L. \& Sillanpää, M. 2020. Recent advances in removal techniques of $\mathrm{Cr}(\mathrm{VI})$ toxic ion from aqueous solution: A comprehensive review. Journal of Molecular Liquids 2020: 115062. https://doi. org/10.1016/j.molliq.2020.115062.

Koushkbaghi, S., Zakialamdari, A., Pishnamazi, M., Ramandi, H.F., Aliabadi, M. \& Irani, M. 2018. Aminated-Fe3O4 nanoparticles filled chitosan/PVA/PES dual layers nanofibrous membrane for the removal of $\mathrm{Cr}$ (VI) and $\mathrm{Pb}$ (II) ions from aqueous solutions in adsorption and membrane processes. Chemical Engineering Journal 337: 169-182.

Kumar, R., Anupama, A.V., Kumaran, V. \& Sahoo, B. 2018. Effect of solvents on the structure and magnetic properties of pyrolysis derived carbon globules embedded with iron/iron carbide nanoparticles and their applications in magnetorheological fluids. Nano-Structures \& Nano-Objects 16: 167-173.

Machado, S., Pinto, S.L., Grosso, J.P., Nouws, H.P.A., Albergaria, J.T. \& Delerue-Matos, C. 2013. Green production of zerovalent iron nanoparticles using tree leaf extracts. Science of The Total Environment 445: 1-8.

Mashayekhi, F., Shafiekhani, A., Ali Sebt, S. \& Darabi, E. 2018. The effect of initial pressure on growth of FeNPs in amorphous carbon films. International Nano Letters 8(1): 25-30.

Mehrotra, N., Tripathi, R.M., Zafar, F. \& Singh, M.P. 2017. Catalytic degradation of dichlorvos using biosynthesized zero valent iron nanoparticles. IEEE Transactions on Nanobioscience 16(4): 280-286.

Mohan, D. \& Pittman Jr. C.U. 2006. Activated carbons and low cost adsorbents for remediation of tri-and hexavalent chromium from water. Journal of Hazardous Materials 137(2): 762-811. 
Patel, D., Vithalani, R. \& Modi, C.K. 2020. Highly efficient FeNPembedded hybrid bifunctional reduced graphene oxide for knoevenagel condensation with active methylene compounds. New Journal of Chemistry 44(7): 2868-2881.

Paunovic, J., Vucevic, D., Radosavljevic, T., Mandić-Rajčević, S. \& Pantic, I. 2020. Iron-based nanoparticles and their potential toxicity: Focus on oxidative stress and apoptosis. Chemico-Biological Interactions 316: 108935.

Plachtová, P., Medrikova, Z., Zboril, R., Tucek, J., Varma, R.S. \& Maršálek, B. 2018. Iron and iron oxide nanoparticles synthesized with green tea extract: Differences in ecotoxicological profile and ability to degrade malachite green. ACS Sustainable Chemistry \& Engineering 6(7): 8679-8687.

Qian, A., Liao, P., Yuan, S. \& Luo, M. 2014. Efficient reduction of $\mathrm{Cr}(\mathrm{VI})$ in groundwater by a hybrid electro-Pd process. Water Research 48: 326-334.

Shalaby, A.A. \& Mohamed, A.A. 2020. Sensitive assessment of hexavalent chromium using various uniform and non-uniform color space signals derived from digital images. Water, Air, \& Soil Pollution 231(10): 1-10.

Sun, Q., Hu, X., Zheng, S., Zhang, J. \& Sheng, J. 2019. Effect of calcination on structure and photocatalytic property of N-TiO2/g-C3N4@ diatomite hybrid photocatalyst for improving reduction of Cr (VI)'. Environmental Pollution 245: 53-62.

Wang, Q., Huang, L., Pan, Y., Quan, X. \& Puma, G.L. 2017. Impact of $\mathrm{Fe}$ (III) as an effective electron-shuttle mediator for enhanced $\mathrm{Cr}$ (VI) reduction in microbial fuel cells: Reduction of diffusional resistances and cathode overpotentials. Journal of Hazardous Materials 321: 896906.

Wang, T., Jin, X., Chen, Z., Megharaj, M. \& Naidu, R. 2014. Green synthesis of Fe nanoparticles using eucalyptus leaf extracts for treatment of eutrophic wastewater. Science of The Total Environment 466: 210-213.

Wang, W., Hu, B., Wang, C., Liang, Z., Cui, F., Zhao, Z. \& Yang, C. 2020. 'Cr (VI) removal by micron-scale iron-carbon composite induced by ball milling: The role of activated carbon. Chemical Engineering Journal 389: 122633.

Wei, S., Li, D., Huang, Z., Huang, Y. \& Wang, F. 2013. Highcapacity adsorption of $\mathrm{Cr}$ (VI) from aqueous solution using a hierarchical porous carbon obtained from pig bone. Bioresource Technology 134: 407-411.

Wei, Y., Fang, Z., Zheng, L. \& Tsang, E.P. 2017. Biosynthesized iron nanoparticles in aqueous extracts of Eichhornia crassipes and its mechanism in the hexavalent chromium removal. Applied Surface Science 399: 322-329.

Xu, Y., Lu, Y., Zhang, P., Wang, Y., Zheng, Y., Fu, L., Zhang, H., Lin, C-T. \& Yu, A. 2020. Infrageneric phylogenetics investigation of chimonanthus based on electroactive compound profiles. Bioelectrochemistry 133: 107455. https:// doi.org/10.1016/j.bioelechem.2020.107455.
Yin, Z., Liu, W., Bao, M. \& Li, Y. 2021. Magnetic chitosan-based aerogel decorated with polydimethylsiloxane: A highperformance scavenger for oil in water. Journal of Applied Polymer Science 2021: 50461.

Ying, J., Zheng, Y., Zhang, H. \& Fu, L. 2020. Room temperature biosynthesis of gold nanoparticles with Lycoris aurea leaf extract for the electrochemical determination of aspirin. Revista Mexicana de Ingeniería Química 19(2): 585-592.

Zeng, Q., Hu, Y., Yang, Y., Hu, L., Zhong, H. \& He, Z. 2019. Cell envelop is the key site for Cr (VI) reduction by Oceanobacillus oncorhynchi W4, a newly isolated Cr (VI) reducing bacterium. Journal of Hazardous Materials 368: 149-155.

Zhang, H-Y., Wang, Y., Xiao, S., Wang, H., Wang, J-H. \& Feng, L. 2017. Rapid detection of $\mathrm{Cr}(\mathrm{VI})$ ions based on cobalt (II)-doped carbon dots. Biosensors and Bioelectronics 87: 46-52.

Zhang, M., Pan, B., Wang, Y., Du, X., Fu, L., Zheng, Y., Chen, F., Wu, W., Zhou, Q. \& Ding, S. 2020. Recording the electrochemical profile of Pueraria leaves for polyphyly analysis. ChemistrySelect 5(17): 5035-5040.

Zhang, X., Yang, R., Li, Z., Zhang, M., Wang, Q., Xu, Y., Fu, L., Du, J., Zheng, Y. \& Zhu, J. 2020. Electroanalytical study of infrageneric relationship of Lagerstroemia using glassy carbon electrode recorded voltammograms. Revista Mexicana de Ingeniería Química 19(Sup. 1): 281-291.

Zhou, J., Zheng, Y., Zhang, J., Karimi-Maleh, H., Xu, Y., Zhou, Q., Fu, L. \& Wu, W. 2020. Characterization of the electrochemical profiles of Lycoris seeds for species identification and infrageneric relationships. Analytical Letters 53(15): 2517-2528. https://doi.org/10.1080/000327 19.2020.1746327.

Haobin Shi, Fei Chen, Li Fu* \& Shichao Zhao

College of Materials and Environmental Engineering

Hangzhou Dianzi University

Hangzhou, 310018

P.R. China

Wenbin Zhang \& Feng Chen

Xinchang Bureau of Agriculture and Rural Affairs

Shaoxing, 312500

P.R. China

Qingsheng Shi

Zhehua Xinnong (Jia Xing) Biotechnological Co., Ltd. P.R. China

*Corresponding author; email: fuli@hdu.edu.cn

Received: 25 January 2021

Accepted: 4 March 2021 